\title{
PREOPERATIVE PREDICTORS OF DIFFICULT LAPAROSCOPIC CHOLECYSTECTOMY: A PROSPECTIVE STUDY
}

Pankaj Kumar Verma ${ }^{1}$, Mukul Singh ${ }^{2}$, Shriranjan Kala ${ }^{3}$, Ashish Jaiswal ${ }^{4}$, Monika Singh ${ }^{5}$

${ }_{1}^{1}$ Associate Professor, Department of Surgery, Govt. Medical College, Haldwani.

${ }^{2}$ Senior Resident, Department of Surgery, Govt. Medical College, Haldwani.

${ }^{3}$ Assistant Professor, Department of Surgery, Govt. Medical College, Haldwani.

${ }_{43}{ }^{\text {rd }}$ Year Junior Resident, Department of Surgery, Govt. Medical College, Haldwani.

${ }^{5}$ BDS, Final Year Student, PIDS, Gorakhpur.

\section{ABSTRACT}

\section{BACKGROUND}

Preoperative difficulty estimation helps deciding whether to proceed with a minimally invasive approach, perform an open procedure or make a referral to a more experienced surgeon. Laparoscopic cholecystectomy outcome is particularly affected by the presence and severity of inflammation, age, male sex, etc.

To determine the preoperative predictive factors for difficult laparoscopic cholecystectomy.

\section{MATERIAL AND METHODS}

A total of 100 patients were enrolled to this study. Clinical examination, laboratory data and ultrasound study was performed for all patients.

\section{CONCLUSION}

Preoperative prediction of risk factors of difficult laparoscopic cholecystectomy is an important point for operative planning and the high risk patients may be informed accordingly.

\section{KEYWORDS}

Predictor's, Difficult Laparoscopic Cholecystectomy.

HOW TO CITE THIS ARTICLE: Verma PK, Singh M, Kala S, et al. Preoperative predictors of difficult laparoscopic cholecystectomy: a prospective study. J. Evolution Med. Dent. Sci. 2016;5(73):5423-5429, DOI: 10.14260/jemds/2016/1229

\section{INTRODUCTION \\ METHODOLOGY}

Laparoscopic Cholecystectomy (LC) has become the gold standard in the treatment of symptomatic gall stones. ${ }^{1} \mathrm{LC}$ has replaced open cholecystectomy as the therapeutic modality in the treatment of Cholelithiasis. ${ }^{1}$ Decreased postoperative pain, earlier oral intake, shorter hospital stay, early resumption of normal activity and improved cosmesis have been well recognised after LC. ${ }^{2} \mathrm{~A}$ significant reduction in the incidence of wound complications and postoperative ileus has been documented in patients undergoing LC. ${ }^{3}$ It is important to realise that the need for conversion to laparotomy is neither a failure nor a complication, but an attempt to avoid complication and ensure patient safety. ${ }^{4}$ Prediction of a difficult Laparoscopic cholecystectomy would allow the surgeon to discuss the likelihood of conversion with the patient and prepare him/her psychologically.4,5 Another benefit would be to allow more efficient scheduling of the operating lists and ensuring the availability of a more experienced laparoscopic surgeon for the procedure. ${ }^{4}$ Our study is based on the assumption that difficult laparoscopic cholecystectomy can be predicted and our study has been designed to identify the associated preoperative predictors.

Financial or Other, Competing Interest: None.

Submission 04-08-2016, Peer Review 30-08-2016,

Acceptance 06-09-2016, Published 12-09-2016.

Corresponding Author:

Dr. Mukul Singh,

Room No. 56, Senior Resident Hostel,

Govt. Medical College,

Haldwani, Nainital, Uttarakhand.

E-mail: singhmukul3911@gmail.com

DOI: $10.14260 /$ jemds/2016/1229

This was a prospective study conducted in Department of Surgery, Dr. Susheela Tiwari, Government Medical College and Associated Government Hospital, Rampur Road, Haldwani, Dist., Nainital, Uttarakhand, from Nov. 2013 to Sept. 2015. The patients who underwent laparoscopic cholecystectomy were included in this study. Total number of patients is 100 and includes both admitted either as routine or emergency cases.

\section{The Following were the Exclusion Criteria Exclusion Criteria}

- The patients who were taken for open cholecystectomy directly.

- Severe restrictive pulmonary disease (These patients cannot tolerate $\mathrm{CO}_{2}$ pneumoperitoneum).

- Suspected gall bladder malignancy.

- Patients unfit for general anaesthesia.

- Patients not giving informed written consent.

The selected patients were then told about the procedure and written informed consent was taken. Patients were also informed about the possibility of conversion to open cholecystectomy. In this study, we have taken preoperative predictors of difficult laparoscopic cholecystectomy. Preoperative predictors were further divided into clinical, biochemical and ultrasonographic predictors.

\section{PREOPERATIVE FACTORS}

\section{Clinical Factors}

1. Age.

2. Sex.

3. Duration of pain.

4. Recurrent biliary colic. 
5. History of jaundice.

6. History of pancreatitis.

7. Previous history of upper abdominal surgery.

8. Gall bladder lump.

9. H/O comorbid conditions like diabetes, hypertension.

\section{Biochemical Factors}

1. Direct bilirubin $>0.4 \mathrm{mg} / \mathrm{dL}$ (normal lab range $0.1-0.4$ $\mathrm{mg} / \mathrm{dL}$ ).

2. Alkaline phosphatase $>306 \mathrm{U} / \mathrm{L}$ (normal lab range $65-306$ $\mathrm{U} / \mathrm{L}$ ).

3. Total Leukocyte Count $>11000$ /cumm (normal lab range 4000-11000/cumm).

\section{Ultrasonographic Factors}

1. Gall bladder wall thickening $>4 \mathrm{~mm} /$ Oedema of Gall bladder wall.

2. Pericholecystic fluid.

3. Contracted Gall bladder.

4. Single/multiple gall stones/location of stones (neck, fundus of gall bladder).

5. Common bile duct diameter/evaluation of cystic duct.

6. Common bile duct stones.

7. Existing comorbid conditions detected on ultrasonography like pancreatitis, cholangitis.

8. Complications like mucocele /emphysematous /gangrenous /fistulous gall bladder.

9. Liver cirrhosis.

\section{OBSERVATIONS AND RESULT}

The findings of pre-operative clinical, biochemical and ultrasonographic factors of all patients were correlated with total duration of surgery and intraoperative difficulties encountered during laparoscopic cholecystectomy to find out the predictors of difficult laparoscopic cholecystectomy.

\begin{tabular}{|c|c|c|}
\hline Age Group (Years) & Total Number & Percentage \% \\
\hline$<20$ & 4 & $4 \%$ \\
\hline $21-30$ & 14 & $14 \%$ \\
\hline $31-40$ & 20 & $20 \%$ \\
\hline $41-50$ & 30 & $30 \%$ \\
\hline $51-60$ & 18 & $18 \%$ \\
\hline$>60$ & 14 & $14 \%$ \\
\hline \multicolumn{3}{|c|}{ Table 1: Age Distribution } \\
\hline
\end{tabular}

Out of 100 patients, 21 (21\%) were Males and 79 (79\%) were Females.

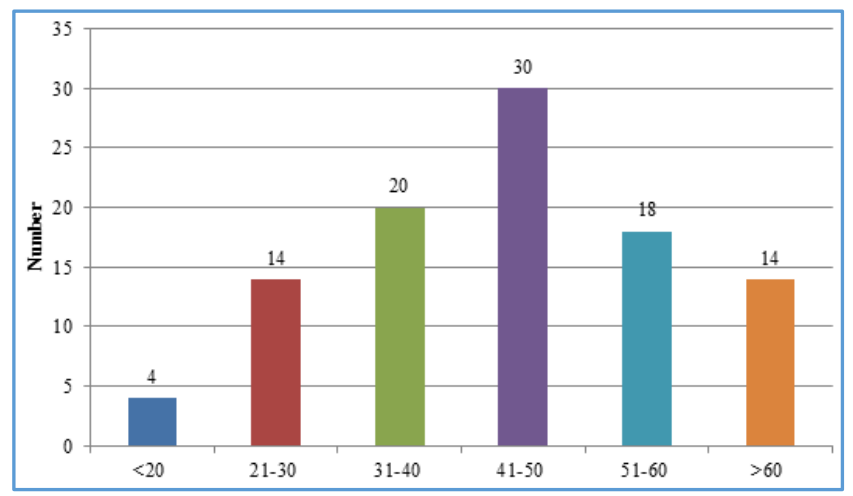

Fig. 1: Age Distribution

\begin{tabular}{|c|c|c|}
\hline Clinical Factors & $\begin{array}{c}\text { Total No. of } \\
\text { Patients }\end{array}$ & $\begin{array}{c}\text { Percentage } \\
\text { \% }\end{array}$ \\
\hline H/0 jaundice & 5 & $5 \%$ \\
\hline H/O biliary pancreatitis & 6 & $6 \%$ \\
\hline Pain <3 days & 3 & $3 \%$ \\
\hline Pain 3-7 days & 64 & $64 \%$ \\
\hline Pain >7 days & 33 & $33 \%$ \\
\hline $\begin{array}{c}\text { Previous upper } \\
\text { abdominal surgery }\end{array}$ & 2 & $2 \%$ \\
\hline Recurrent colic & 80 & $80 \%$ \\
\hline Gallbladder lump & 8 & $8 \%$ \\
\hline \multicolumn{2}{|c|}{ Table 2: Distribution of Clinical Factors } \\
\hline \multicolumn{2}{|c}{}
\end{tabular}

Most frequent clinical presentation was recurrent colic (80 cases), $\mathrm{H} / \mathrm{O}$ jaundice was present in 5 cases, whereas h/o biliary pancreatitis was present in 6 cases; 3 patients presented with h/o pain for less than 3 days. GB lump was palpable in 8 cases; 2 patients had h/o upper abdominal surgery in past.

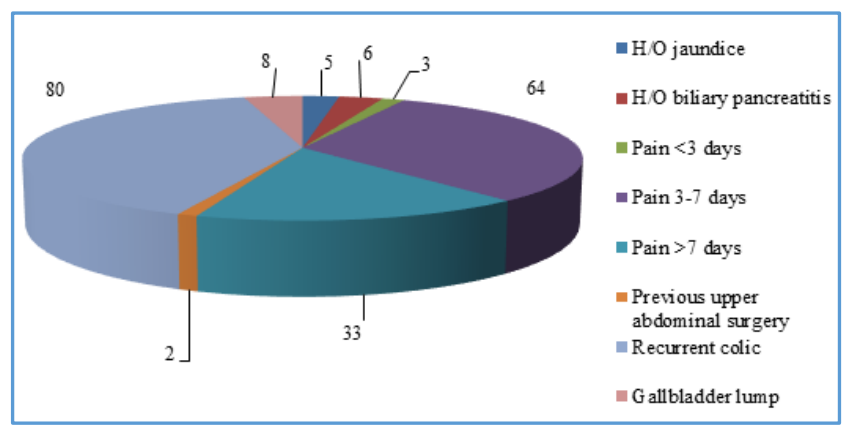

Fig. 2: Distribution of Clinical Factors

\begin{tabular}{|c|c|c|}
\hline $\begin{array}{c}\text { Biochemical } \\
\text { Factors }\end{array}$ & $\begin{array}{c}\text { Total No. of } \\
\text { Patients }\end{array}$ & $\begin{array}{c}\text { Percentage } \\
\%\end{array}$ \\
\hline $\begin{array}{c}\text { Direct bilirubin }>0.4 \\
\text { mg\% }\end{array}$ & 11 & $11 \%$ \\
\hline ALP >306 IU/L & 24 & $24 \%$ \\
\hline TLC > 11000 & 4 & $4 \%$ \\
\hline \multicolumn{2}{|c|}{ Table 3: Distribution of Biochemical Factors } \\
\hline
\end{tabular}

- Analysis of biochemical factors in patients undergoing laparoscopic cholecystectomy showed that Direct bilirubin $>0.4 \mathrm{mg} \%$ was seen in $11(11 \%)$ cases.

- In 24 (24\%) patients, Alkaline Phosphatase was $>306$ $\mathrm{IU} / \mathrm{L}$.

- $4(4 \%)$ patients had TLC $>11,000$.

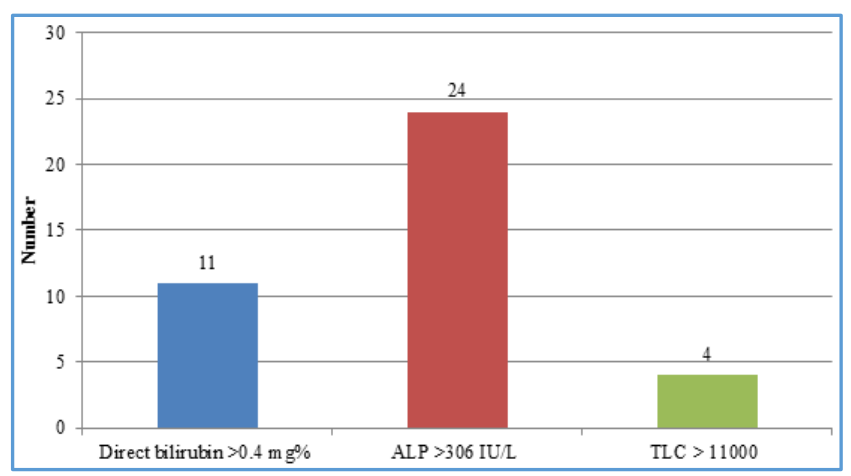

Fig. 3: Distribution of Biochemical Factors 


\begin{tabular}{|c|c|c|}
\hline $\begin{array}{c}\text { Ultrasonographic } \\
\text { Factors }\end{array}$ & $\begin{array}{c}\text { Total No. of } \\
\text { Patients }\end{array}$ & $\begin{array}{c}\text { Percentage } \\
\mathbf{\%}\end{array}$ \\
\hline Single calculus & 20 & $20 \%$ \\
\hline Multiple calculus & 80 & $80 \%$ \\
\hline CBD dilated ( $\geq 6 \mathrm{~mm}$ ) & 17 & $17 \%$ \\
\hline CBD stone & 4 & $4 \%$ \\
\hline $\begin{array}{c}\text { GB wall thickness }>4 \\
\text { mm }\end{array}$ & 22 & $22 \%$ \\
\hline Pericholecystic fluid & 4 & $4 \%$ \\
\hline Contracted GB & 7 & $7 \%$ \\
\hline Distended GB & 47 & $47 \%$ \\
\hline Liver cirrhosis & 4 & $4 \%$ \\
\hline Mucocele GB & 12 & $12 \%$ \\
\hline Empyema GB & 2 & $2 \%$ \\
\hline Gangrenous GB & 1 & $1 \%$ \\
\hline Table 4: Distribution of Ultrasonographic Factors \\
\hline
\end{tabular}

- Analysis of ultrasonographic factors showed that most frequent finding was multiple calculi $80(80 \%)$ cases.

- Next most common finding on ultrasonography was distended GB 47 (47\%) cases.

- $\quad$ Patients with Gallbladder wall thickness $>4$ mm were 22 cases $(22 \%)$.

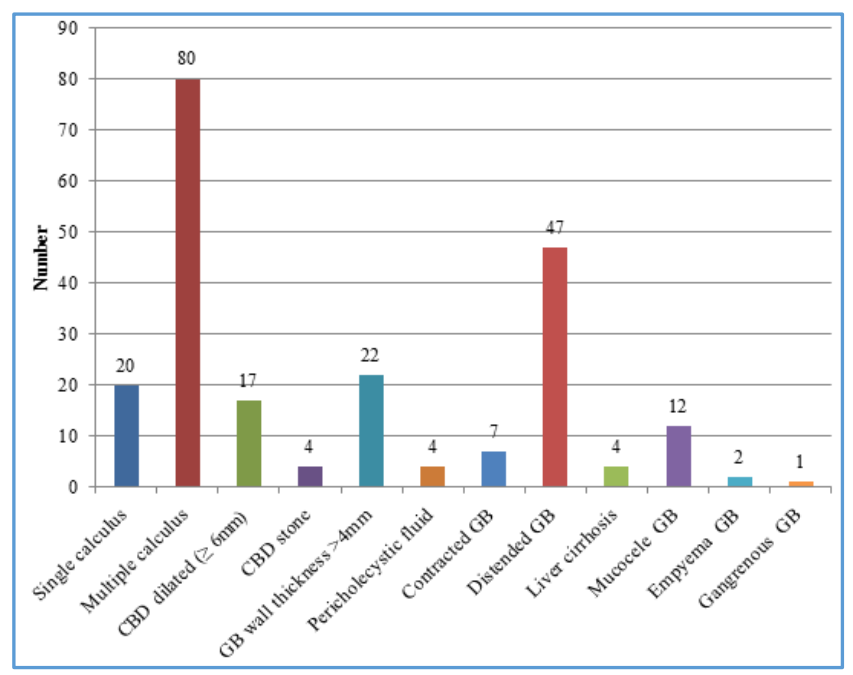

Fig. 4: Distribution of Ultrasonographic Factors
- Analysis of ultrasonographic factors showed that most frequent finding was multiple calculi 80 (80\%) cases.

- Next most common finding on ultrasonography was distended GB 47 (47\%) cases.

- Patients with Gallbladder wall thickness > 4 mm were 22 cases $(22 \%)$.

- Patients with Pericholecystic fluid 4 (4\%) cases, Contracted gallbladder 7 (7\%) cases and Liver cirrhosis 4 $(4 \%)$ cases.

\begin{tabular}{|c|c|c|c|}
\hline Time (min) & Total No. & Male & Female \\
\hline$<30$ & 0 & 0 & 0 \\
\hline $31-60$ & 73 & 9 & 64 \\
\hline $61-90$ & 4 & 0 & 4 \\
\hline $91-120$ & 20 & 10 & 10 \\
\hline$>120$ & 3 & 2 & 1 \\
\hline Conversion & 5 & 4 & 1 \\
\hline \multicolumn{2}{|c|}{ Table 5: Distribution of Total Duration of Surgery } \\
\hline
\end{tabular}

- The above table shows that 77 cases were completed within 90 minutes, out of which 68 were females and 9 were males; 3 cases took more than 2 hours, out of which 2 cases were males and 1 case was female.

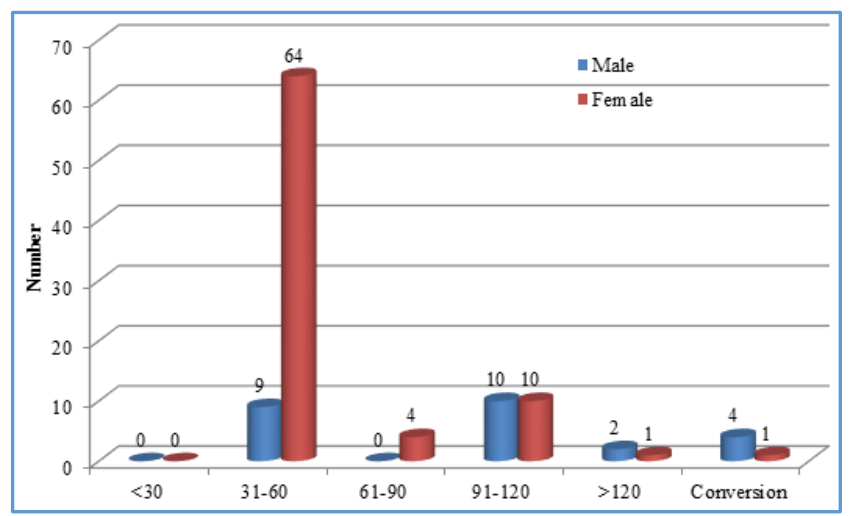

Fig. 5: Distribution of Total Duration of Surgery

\begin{tabular}{|c|c|c|c|c|c|}
\hline \multirow[t]{2}{*}{ Clinical Factors } & \multirow{2}{*}{$\begin{array}{c}\text { Total Number of } \\
\text { Patients }\end{array}$} & \multicolumn{2}{|c|}{$\begin{array}{c}\text { Laparoscopic } \\
\text { Cholecystectomy }\end{array}$} & \multicolumn{2}{|c|}{$\begin{array}{l}\text { Laparoscopic } \\
\text { Cholecystectomy }\end{array}$} \\
\hline & & Difficult & Easy & Difficult \% & Easy \% \\
\hline Age $>60$ yrs. & 14 & 7 & 7 & 50.00 & 50.00 \\
\hline Male & 21 & 11 & 10 & 52.38 & 47.62 \\
\hline Female & 79 & 15 & 64 & 18.99 & 81.01 \\
\hline $\mathrm{H} / \mathrm{O}$ jaundice & 5 & 3 & 2 & 60.00 & 40.00 \\
\hline $\mathrm{H} / \mathrm{O}$ biliary pancreatitis & 6 & 3 & 3 & 50.00 & 50.00 \\
\hline Pain $<3$ days & 3 & 1 & 2 & 33.33 & 66.67 \\
\hline Pain 3-7 days & 64 & 17 & 47 & 26.56 & 73.44 \\
\hline Pain $>7$ days & 33 & 7 & 26 & 21.21 & 78.79 \\
\hline $\begin{array}{l}\text { Previous upper abdominal } \\
\text { surgery }\end{array}$ & 2 & 2 & 0 & 100.00 & 0.00 \\
\hline Recurrent colic & 80 & 21 & 59 & 26.25 & 73.75 \\
\hline Gallbladder lump & 8 & 3 & 5 & 37.50 & 62.50 \\
\hline
\end{tabular}


Laparoscopic cholecystectomy was difficult in 21 cases (25.90\%) with recurrent colic, 12 cases (15.19\%) of laparoscopic cholecystectomy was difficult in female patients; whereas in male patients in $61.90 \%$ of cases laparoscopic cholecystectomy was difficult.

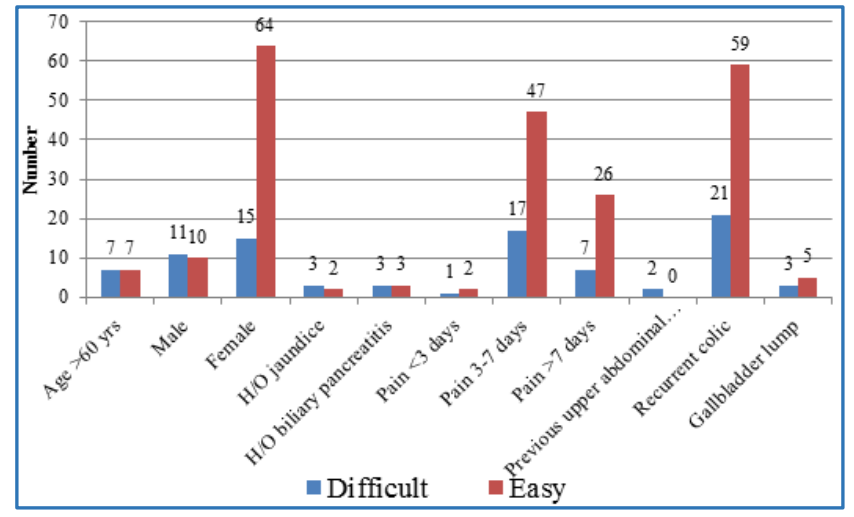

Fig. 6: Difficult Assessment in Relation to Clinical Factors

\begin{tabular}{|c|c|c|c|c|c|}
\hline \multirow{2}{*}{ 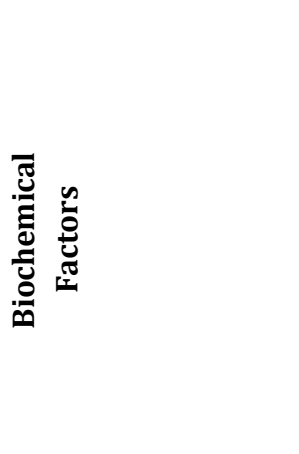 } & \multirow{2}{*}{ 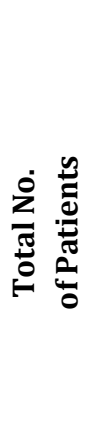 } & \multicolumn{2}{|c|}{ 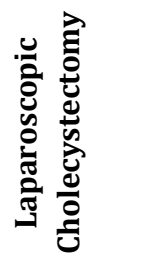 } & \multicolumn{2}{|l|}{ 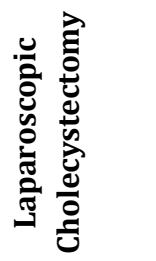 } \\
\hline & & $\underbrace{ \pm}$ & 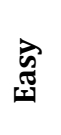 & 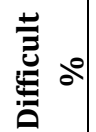 & 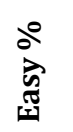 \\
\hline $\begin{array}{c}\text { Direct bilirubin }>0.4 \\
\mathrm{mg} \%\end{array}$ & 11 & 8 & 3 & 72.7 & 27.3 \\
\hline ALP > $306 \mathrm{IU} / \mathrm{L}$ & 24 & 10 & 14 & 41.7 & 58.3 \\
\hline TLC > 11000 & 4 & 4 & 0 & 100 & 0 \\
\hline \multicolumn{6}{|c|}{$\begin{array}{c}\text { Table 7: Difficulty Assessment in Relation } \\
\text { to Biochemical Factors }\end{array}$} \\
\hline
\end{tabular}

Out of 11 cases with direct bilirubin $>0.4 \mathrm{mg} \% 8$ cases (72.70\%) of laparoscopic cholecystectomy was difficult; in 24 patients Alkaline Phosphatase was $>306 \mathrm{IU} / \mathrm{L}$, in them 10 cases $(41.70 \%)$ of laparoscopic cholecystectomy were difficult, 4 patients had TLC > 11000 and in all of them laparoscopic cholecystectomy was difficult.

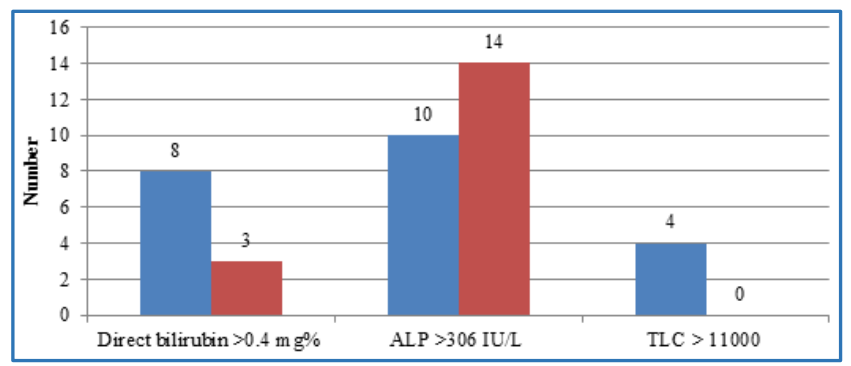

Fig. 7: Difficult Assessment in Relation to Biochemical Factors

\begin{tabular}{|c|c|c|c|c|c|}
\hline \multirow[t]{2}{*}{ 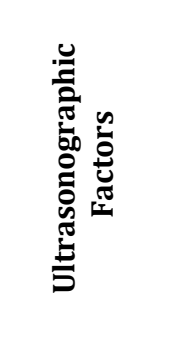 } & \multirow[t]{2}{*}{ 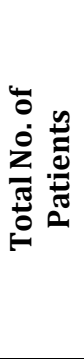 } & \multicolumn{2}{|c|}{ 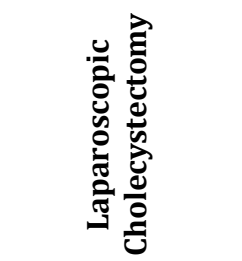 } & \multicolumn{2}{|c|}{ 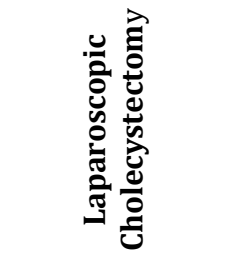 } \\
\hline & & $\begin{array}{c}\text { Difficult } \\
\%\end{array}$ & $\begin{array}{c}\text { Easy } \\
\%\end{array}$ & $\begin{array}{c}\text { Difficult } \\
\%\end{array}$ & $\begin{array}{c}\text { Easy } \\
\%\end{array}$ \\
\hline $\begin{array}{c}\text { Single } \\
\text { calculus }\end{array}$ & 20 & 3 & 17 & 14.29 & 80.95 \\
\hline $\begin{array}{l}\text { Multiple } \\
\text { calculus }\end{array}$ & 80 & 22 & 58 & 27.85 & 73.42 \\
\hline $\begin{array}{l}\text { CBD dilated } \\
(\geq 6 \mathrm{~mm})\end{array}$ & 17 & 11 & 6 & 64.71 & 35.29 \\
\hline CBD stone & 4 & 4 & 0 & 100.00 & 0.00 \\
\hline $\begin{array}{c}\text { GB wall } \\
\text { thickness }\end{array}$ & 22 & 18 & 4 & 81.82 & 18.18 \\
\hline $\begin{array}{l}\text { Pericholecy } \\
\text { stic fluid }\end{array}$ & 4 & 4 & 0 & 100.00 & 0.00 \\
\hline $\begin{array}{c}\text { Contracted } \\
\text { GB } \\
\end{array}$ & 7 & 7 & 0 & 100.00 & 0.00 \\
\hline $\begin{array}{l}\text { Distended } \\
\text { GB } \\
\end{array}$ & 47 & 15 & 32 & 31.91 & 68.09 \\
\hline $\begin{array}{c}\text { Liver } \\
\text { cirrhosis }\end{array}$ & 4 & 4 & 0 & 100.00 & 0.00 \\
\hline Mucocele & 12 & 6 & 6 & 50.00 & 50.00 \\
\hline Empyema & 2 & 2 & 0 & 100.00 & 0.00 \\
\hline Gangrenous & 1 & 1 & 0 & 100.00 & 0.00 \\
\hline
\end{tabular}

- Out of 80 cases with multiple calculi on ultrasonography, 22 cases $(27.5 \%)$ of laparoscopic cholecystectomy was difficult, $15(31.9 \%)$ cases with distended GB out of 47 cases of laparoscopic cholecystectomy were difficult.

- In patients with gallbladder wall thickness $>4 \mathrm{~mm}(22$ cases), 77.3\% (17 cases) of laparoscopic cholecystectomy were difficult.

- In patients with Pericholecystic fluid (4 cases), contracted gallbladder (7 cases) and Liver cirrhosis (4 cases), all laparoscopic cholecystectomies were difficult.

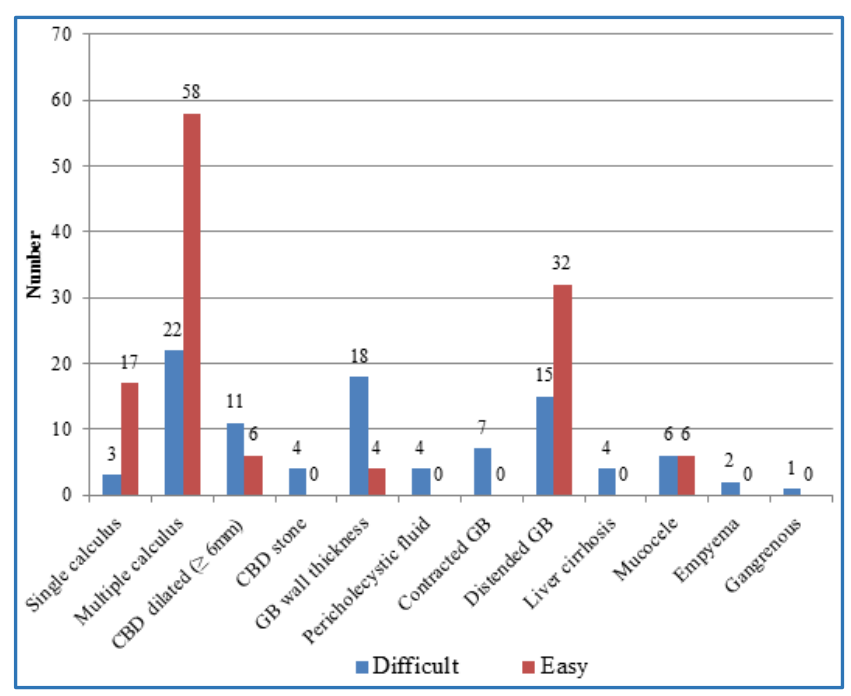

Fig. 8: Difficult Assessment in Relation to Ultrasonographic Factors 


\begin{tabular}{|c|c|c|}
\hline Clinical Factors & $\begin{array}{c}P \\
\text { Value }\end{array}$ & $\begin{array}{c}\text { Factors } \\
\text { Significant }\end{array}$ \\
\hline Age $>60$ yrs. & 0.67 & NS \\
\hline Male & 0.003 & $*$ \\
\hline $\mathrm{H} / \mathrm{O}$ jaundice & 0.71 & NS \\
\hline $\mathrm{H} / \mathrm{O}$ biliary pancreatitis & 0.42 & NS \\
\hline Pain $<3$ days & 0.000 & * \\
\hline $\begin{array}{c}\text { Previous upper abdominal } \\
\text { surgery }\end{array}$ & 0.003 & $*$ \\
\hline Recurrent colic & 0.79 & NS \\
\hline \multicolumn{3}{|c|}{ Table 9: Statistical Analysis of Clinical Factors } \\
\hline
\end{tabular}

NS $=$ Non-Significant, ${ }^{*}=$ Significant

\begin{tabular}{|c|c|c|}
\hline Biochemical Factors & $\begin{array}{c}\mathbf{P} \\
\text { Value }\end{array}$ & $\begin{array}{c}\text { Factors } \\
\text { Significant }\end{array}$ \\
\hline $\begin{array}{c}\text { Direct bilirubin }>0.4 \\
\mathrm{mg} \%\end{array}$ & 0.001 & $*$ \\
\hline $\mathrm{ALP}>306 \mathrm{IU} / \mathrm{L}$ & 0.53 & NS \\
\hline TLC $>11000$ & 0.37 & NS \\
\hline
\end{tabular}

NS $=$ Non-Significant, $*$ = Significant

\begin{tabular}{|c|c|c|}
\hline $\begin{array}{l}\text { Ultrasonographic } \\
\text { Factors }\end{array}$ & $\begin{array}{c}P \\
\text { Value }\end{array}$ & $\begin{array}{c}\text { Factors } \\
\text { Significant }\end{array}$ \\
\hline Single calculus & 0.097 & NS \\
\hline Multiple calculus & 0.002 & $*$ \\
\hline CBD dilated $(\geq 6 \mathrm{~mm})$ & 0.011 & $*$ \\
\hline CBD stone & 0.76 & NS \\
\hline GB wall thickness & 0.001 & $*$ \\
\hline Pericholecystic fluid & 0.34 & NS \\
\hline Contracted GB & 0.42 & NS \\
\hline Distended GB & 0.018 & $*$ \\
\hline Liver cirrhosis & 0.62 & NS \\
\hline \multicolumn{3}{|c|}{$\begin{array}{c}\text { Table 11: Statistical Analysis of } \\
\text { Ultrasonographic Factors }\end{array}$} \\
\hline
\end{tabular}

NS $=$ Non-significant ${ }^{*}=$ Significant

\section{DISCUSSION}

This study was done to find out the predictors of difficult laparoscopic cholecystectomy by analysis of pre-operative clinical, biochemical and ultrasonographic factors. The statistically significant factors in our study, which can predict difficult laparoscopic cholecystectomy were:

a. Gallbladder wall thickness $>4 \mathrm{~mm}(\mathrm{n}=22 ; \mathrm{p}$ value $=0.001)$

b. Pain $<3$ days $(n=3$; $p$ value $=0.000)$

c. Dilated CBD $(n=17 ; \mathrm{p}$ value $=0.011)$

d. Distended GB $(n=47 ; p$ value $=0.018)$

e. Male gender $(n=21 ; p$ value $=0.003)$

f. History of previous upper abdominal surgery $(n=2 ; p$ value $=0.003$ )

g. Direct bilirubin $>0.4 \mathrm{mg} \%(\mathrm{n}=11 ; \mathrm{p}$ value $=0.001)$

h. Multiple stones in GB $(n=80 ; p$ value $=0.002)$

\section{Gallbladder Wall Thickness}

In our study gallbladder wall thickness $>4 \mathrm{~mm}$ was seen in 22 patients, out of which 18 laparoscopic cholecystectomies were difficult. So, it is statistically highly significant predictor for difficult laparoscopic cholecystectomy ( $p$ value=0.001). Fried et al reported that thickened gallbladder wall was significant predictor of conversion of Laparoscopic to open cholecystectomy.(6)

\section{Acute Cholecystitis}

According to Rattner DW et al, the changes that occur with acute cholecystitis are oedema, hypervascularity, venous engorgement and gallbladder distention. Within 72 hours of symptoms the tissue planes are oedematous and inflamed, but are easier to dissect, having no adhesions at all. But after 72 hours, the tissue becomes more friable and becomes dangerous and risky to dissect.(7)

In our study also 4 patients presented with acute cholecystitis and in all of them laparoscopic cholecystectomy was difficult. This may be because all of them presented after 72 hours of onset of symptoms; 2 patients had empyema of gallbladder, but both of them were completed successfully with laparoscopic cholecystectomy.

\section{Male Gender}

In our study out of 21 male patients, 11 had difficult laparoscopic cholecystectomy. It is statistically significant predictor for difficult laparoscopic cholecystectomy ( $p$ value $=0.003$ ).

Nachnani J in his study also reported that male gender was a significant predictor for difficult laparoscopic cholecystectomy.(8)

Fried et al reported that male gender was a significant predictor of conversion of Laparoscopic cholecystectomy to open cholecystectomy.(6)

\section{Previous Upper Abdominal Surgery}

In our study, h/o previous upper abdominal surgery was present in 2 cases and both turned out to be difficult. It is statistically significant predictor for difficult laparoscopic cholecystectomy ( $\mathrm{p}$ value $=0.003$ ).

The published prospective study by Nachnani J reported that past history of upper abdominal surgery is a significant clinical predictor of difficult laparoscopic cholecystectomy.(8)

\section{Direct Bilirubin > $0.4 \mathrm{mg} \%$}

In our study, we observed that Direct bilirubin $>0.4 \mathrm{mg} \%$ is statistically significant factor for prediction of difficult laparoscopic cholecystectomy. Direct bilirubin was raised in 11 patients, out of which laparoscopic cholecystectomy turned out to be difficult in 8 patients ( $p$ value $=0.001$ ). Del Pin CA et al published a study of the relationship of pathology and operative time and outcome of laparoscopic cholecystectomy in both acute and chronic cholecystitis cases, which concluded that abnormal liver function tests are associated with longer operative time. ${ }^{(9)}$

\section{Multiple Gallbladder Calculi}

In our study also multiple GB calculi ( $p$ value=0.002) is statistically significant predictor for difficult laparoscopic cholecystectomy. Among 80 patients who were having multiple calculi, 22 cases turned out to be difficult.

According to Y. K. S. Vishwanath, retrieval of gall bladder through the port site opening is technically difficult and challenging when it is packed with multiple calculi.(10)

\section{Distended Gallbladder}

In our study among 47 patients who were having distended gall bladder, 15 cases turned out to be difficult which is statistically significant ( $\mathrm{p}$ value $=0.018$ ) . 
Daradekh S also concluded that gallbladder size was a significant predictor of the variation in overall difficulty score.(11)

\section{Age $>60$ Years}

In our study, total number of patients with age $>60$ years were 14 and 7 cases turned out to be difficult. Although, it is statistically insignificant ( $p$ value $=0.67$ ) factor for predicting difficult laparoscopic cholecystectomy, but we encountered problems during dissection in Calot's triangle in 6 patients and omental and duodenal adhesions to gall bladder was present in 4 patients. Gallbladder wall was also thickened in 4 cases.

Ammori B J et al reported age older than 55 years as a predictor of extended operation time (more than 90 minutes).

Fried et al reported that increasing age was a significant predictor of conversion of Laparoscopic cholecystectomy to open cholecystectomy. ${ }^{(6)}$

\section{H/O Jaundice}

In our study, $\mathrm{h} / \mathrm{o}$ jaundice is an insignificant ( $\mathrm{p}$ value $=0.71$ ) predictor for difficult laparoscopic cholecystectomy. The study by Del Pin CA et al concluded that abnormal liver function tests are associated with longer operative time. ${ }^{(9)}$

\section{Recurrent Biliary Colic}

Recurrent biliary colic ( $\mathrm{n}=80$; $\mathrm{p}$ value $=0.79$ ) is statistically insignificant factors in our study.

\section{Gallstone (Biliary) Pancreatitis}

In our study, h/o gallstone pancreatitis was present in 6 cases only 2 surgeries were difficult amongst them. It is statistically insignificant factor to predict difficult laparoscopic cholecystectomy ( $\mathrm{p}$ value $=0.42$ )

According to Nachnani J et al, history of biliary pancreatitis is a significant predictor for difficult laparoscopic cholecystectomy. ${ }^{(8)}$

\section{Serum Alkaline Phosphatase $>306$ IU/L}

In our study, we observed that serum alkaline phosphatase > $306 \mathrm{IU} / \mathrm{L}$ was present in 24 cases and only 10 cases were difficult. It is statistically insignificant factor for prediction of difficult laparoscopic cholecystectomy ( $\mathrm{p}$ value $=0.53$ ).

Rattner et al concluded that raised serum alkaline phosphatase was associated with severe inflammation and failure of laparoscopic cholecystectomy. The significant parameter identified was elevated alkaline phosphatase level.(7)

\section{TLC > 11, $000 \mathrm{cu} / \mathrm{mm}$}

In our study we observed that TLC $>11,000 \mathrm{cu} / \mathrm{mm}$ was present in 4 cases and all of them turned out to be difficult, yet it is statistically insignificant factor for prediction of difficult laparoscopic cholecystectomy ( $\mathrm{p}$ value $=0.37$ ).

A study conducted by Rattner et al to determine the preoperative factors that correlate with successful completion of a laparoscopic cholecystectomy in patients with acute cholecystitis, which showed that the clinical parameters with severe inflammation were significantly associated with failure of laparoscopic procedure. The significant parameter identified was leucocytosis.(7)

\section{Pericholecystic Fluid}

In our study, pericholecystic fluid on sonography was seen in 4 patients and in all of them laparoscopic cholecystectomy was difficult, yet it is statistically insignificant factor in predicting difficult laparoscopic cholecystectomy ( $\mathrm{p}$ value $=0.34$ ).

Hans-Peter Dinkel et al reported that on sonography pericholecystic fluid is a most specific indicator of technical difficulties during laparoscopic cholecystectomy.(12)

\section{Contracted Gallbladder}

In our study, we observed that laparoscopic cholecystectomy was difficult in all 7 patients with contracted gallbladder. Though statistically insignificant may be because of small number of cases, contracted gallbladder with thick-walled gallbladder is a strong predictor of difficult laparoscopic cholecystectomy ( $\mathrm{p}$ value 0.001 ).

Lal $\mathrm{P}$ et al reported that contracted gallbladder on ultrasonography was a predictor of difficult laparoscopic cholecystectomy.(13)

\section{Liver Cirrhosis}

In our study liver cirrhosis was present in 4 cases and all of them were difficult laparoscopic cholecystectomies, yet it is statistically insignificant ( $\mathrm{p}$ value $=0.62$ ) factor for predicting difficult laparoscopic cholecystectomy.

Zakro et al published a study of 24 liver cirrhotic patients who underwent laparoscopic cholecystectomy. The index of conversion was $4.16 \%(1 / 24)$ and mortality rate 0 . The mean length of hospital stay was 2.9 days. The study concluded that use of laparoscopic cholecystectomy for gallstone disease is proposed in patients with liver cirrhosis as the first choice operative method for treatment.(14)

Dilated Common Bile Duct and Common Bile Duct Stones In our study, dilated common bile duct $>6 \mathrm{~mm}$ is statistically significant predictor for difficult laparoscopic cholecystectomy ( $\mathrm{p}$ value $=0.011$ ). Common bile duct was dilated in 17 patients, out of which 11 cases turned out to be difficult. Presence of common bile duct stones is statistically insignificant predictor of laparoscopic cholecystectomy ( $\mathrm{n}=4$, $\mathrm{p}$ value $=0.76$ ). Jansen $\mathrm{S}$ concluded that common bile duct diameter wider than $6 \mathrm{~mm}$ was found to increase significantly the risk of conversion of laparoscopic to open cholecystectomy.(15)

\section{CONCLUSION}

From the study we conclude that clinical, biochemical and ultrasonographic parameters collectively can help to predict difficult laparoscopic cholecystectomy in majority of the cases. These predictors can help the surgeon to get an idea of potential difficulty that he can face in that particular patient. On the basis of predictors, one can plan whether surgical laparoscopic trainee should do a particular case in learning phase or not.

On the basis of these predictors we can also know the approximate total time taken for surgery, so that operation theatre timings can be better planned in major institutions where time factor is very important. The best way to avoid complication is to anticipate it beforehand and take precautions accordingly. This will help the surgeon to select patients for laparoscopic cholecystectomy. 


\section{REFERENCES}

1. Palanivelu C. Laparoscopic cholecystectomy. In: Parthasarathi R. edr. Art of laparoscopic surgery-textbook and atlas. $1^{\text {st }}$ edn. India: Jaya Publications 2005:555-83.

2. Udwadia TE. Laparoscopic cholecystectomy. In: Udwadia TE. edr. Laparoscopic surgery in developing countries. $1^{\text {st }}$ edn. New Delhi: Jaypee Brothers 1997:84-6.

3. Traverso LW. Carl Langenbech and the first cholecystectomy. Am J Surg 1976;132(1):81-82.

4. Hunter JG, Trus T. Laparoscopic cholecystectomy. In: Nyhus LM, Baker RJ, Fischer JE. eds. Mastery of surgery. $3^{\text {rd }}$ edn. Boston: Little Brown and company 1997; p. 1098.

5. Ohri A, Singh K. Difficult laparoscopic cholecystectomy: a large series from north India. Indian J Surg 2006;68(4):205-08.

6. Fried GM, Barkun JS, Sigman HH, et al. Factors determining conversion to laparotomy in patients undergoing laparoscopic cholecystectomy. Am J Surg 1994;167(1):3541.

7. Rattner DW, Ferguson C, Warshaw AL. Factors associated with successful laparoscopic cholecystectomy for acute cholecystitis. Ann Surg 1993;217(3):233-6.

8. Nachnani J, Supe A. Pre-operative prediction of difficult laparosopic cholecystectomy using clinical and ultrasonographic parameters. Indian J Gastroenterol 2005; 24(1):16-8.
9. Pin DCA, Arthur KS, Hoing C, et al. Laproscopic cholecystectomy: relationship of pathology and operative time. JSLS 2002;6(2):149-54.

10. Vishwanath YK, Wynne KS. Use of fistula director to enlarge the port site opening to retrieve a stone packed bulky gallbladder during laparoscopic cholecystectomy: a simple and safe technique. J R Coll Surg Edinb 1999;44(3):179-80.

11. Daradekh S. Laparoscopic cholecystectomy: what are the factors determining difficulty? Hepatogastroenterology 2001;48(37):76-8.

12. Dinkel HP, Kraus S, Heimbucher J, et al. Sonography for selecting candidates for laparoscopic cholecystectomy: a prospectve study. AJR 2000;174(5):1433-9.

13. Lal P, Agarwal PN, Malik VK, et al. A difficult laparoscopic cholecystectomy that requires conversion to open procedure can be predicted by preoperative ultrasonography. JSLS 2002;6(1):59-63.

14. Rasic Z, Bakula B, Zoricic I, et al. Laparoscopic cholecystectomy in cirrhotic patients. Acta Clin Croat 2002;41:229-31.

15. Jansen S, Jorgensen J, Caplehorn J, et al. Preoperative ultrasound to predict conversion in laparoscopic cholecystectomy. Surg Laparosc Endosc 1997;7(2): 121-3. 